\title{
Electric Buses in Urban Transport-The Situation and Development Trends
}

\author{
Jakub Slavík \\ Self-employed business consultant, Řičany u Prahy 25101, Czech Republic
}

\begin{abstract}
A study called "E-mobilita v MHD" (e-mobility in urban mass transit) has been conducted by the author's private consultancy to inform Czech public transport operators about the technologies and operational experience to date and stimulate the e-bus utilization as well as their involvement in e-bus research and development projects. The study covers trolley-buses, diesel hybrids and e-buses including fuel cell buses. These electric urban buses have been compared with combustion engine vehicles represented by diesel and CNG (compressed natural gas) buses, in terms of energy consumption and cost, greenhouse gas emissions, noise and life cycle cost. Relations between urban transport e-mobility and the "smart grid" concept have been presented as well. Comprehensive reports prepared on the European Union and the USA levels have been the basis for the study, completed by information from the field research, focused especially on the bus operational reliability and other parameters important for a transport operator and covering, interalia, 12 case studies. The results show electric buses as a promising urban transport mode with massive technology development overcoming their operational limitations. Synergies between electric buses and other urban systems, such as power supply, are notable as well.
\end{abstract}

Key words: Electric bus, trolley-bus, fuel cell bus, charging, urban transport.

\section{Introduction}

Electric powertrains for urban buses are undergoing fast development in both technological and market fields - however, not always noticed by their potential users, i.e., bus operators, and the public transport contractors. Many common stereotypes do not always apply any more, e.g., about "over-expensive" electric buses, "unreliable" diesel hybrids or "unproven" fuel cell buses. A study called "E-mobilita v MHD" (or "the e-mobility in urban mass transit" in English-hereafter "the study") has therefore been conducted by the author's private consultancy for the Czech Transport Company Association to inform the stakeholders about the electric bus development and stimulate their interest in these environment friendly vehicles and hence, the electric bus market.

The key reason for conducting a new, separate study instead of just translating available documents from the

Corresponding author: Jakub Slavík, MBA, principal consultant, research field: public transport. E-mail: slavik.jakub@volny.cz.
European Union and the USA (e.g., Refs. [1, 2]) was that they were either rather general, not containing practical examples, or too much focused on a single powertrain type. Their results have also been somewhat mutually incomparable.

Therefore, it was decided to adopt a managerial, rather than technological, approach to the problem and to adapt the used methodology to the readers-managers and other decision makers from operational practice and public administration. The results of the previously mentioned two key sources have been completed by findings from operational practice and put on a comparable basis as much as possible, preferring instructiveness to exactness if necessary.

The study has been conducted in partnership with the following bus and electric equipment manufacturers: ABB, Cegelec, EVC Group, Siemens, Solaris, SOR, Škoda Electric and Volvo. The study partners provided the study with their latest product information and they also co-sponsored the study as 
their promotion. Doing this, they accepted the author's requirements for the information content, structure and relevance, to avoid "promotion stories" instead of relevant facts. The operational data were supplied by transport operators or found in publicly available sources, such as project web sites.

The TOP-EXPO agency, together with the Proelektrotechniky.cz portal operated by the author's firm, have been the study media partners, supporting the wide presentation of its results.

The study has been made publicly available in summer 2013. Now, about one year after the study's publishing, it is obvious that the study aim was met, as the growing interest in electric buses by the Czech operators and other stakeholders shows. There is also much new information available since then (e.g., Ref. [3] or new project information ${ }^{1}$ ), enough to update and enlarge the study. The market will tell whether, when and how this will be done.

\section{Study Scope, Methodology and Input Data}

\subsection{Study Objectives, Scope and Methodology}

As indicated in the introduction, the study's primary objective is to inform Czech public transport operators and their owners about the electric bus technologies, operational experience and expected development and to stimulate the interest in e-bus operation and involvement in the related development projects. The broader objective is to inform Government bodies and other important stakeholders concerned, through the National Electro-Mobility Association, about the e-bus strategic opportunities, together with the need for

\footnotetext{
${ }^{1}$ Field data from the following sources: The Ministry of Transport, The National Association of Electro-mobility and Modern Technologies, The Czech Technical University in Prague-Faculty of Transportation Sciences, The Ostrava Transport Company, EKOVA ELECTRIC a.s., ÚJV Řež, a. s., the Prague Transport Company, Transport for London (the UK) and SunLine Transit Agency (USA); product and operational information from the study partners; published outputs of HyFleet: CUTE, 100 Bus Electriques and Trolley projects; dedicated media: Proelektrotechniky.cz, Fuel Cell Today, Railway Gazette International and Eltis.org. (altogether referred to as "the field data").
}

resourcing from public funds.

This study objectives imply that the principal approach to the problem solution has to be based on strategic business management, as defined, e.g., by Johnson et al. [4] and applied in the specific public sector conditions, e.g., by Chapman and Cowdell [5]. In terms of this theory (as well as rich practice), the study may be an important part of the strategic analysis, both for the public service organizations concerned and for private companies involved as suppliers.

Standard urban bus type (12 m or comparable) in standard urban line operation has been under the study key focus. Possible differences are explained below.

The vehicle industry market life cycle has been used as the electric bus classification guideline:

- Trolley-bus as a product in the mature market stage;

- Diesel hybrid bus as a product in the market growth stage;

- Electric bus (independent of catenary), both with battery and/or capacitor energy storage and with fuel cell as the primary energy source, as a product in the market development stage.

To avoid misunderstandings, in this paper:

- Electric buses using batteries and/or capacitors as the only energy storages are called "e-buses";

- E-buses with energy storage capacity big enough to be charged just once a day in the depot are called "overnight e-buses" while e-buses with lower energy storage capacity that need to be recharged also during the day shift (often several times) are called "opportunity e-buses";

- Electric buses using fuel cells as primary energy sources (sole or in hybrid combination with batteries and/or capacitors) are called "fuel cell buses" or "fc-buses";

- Diesel hybrid buses, unless precisely specified, cover both serial diesel hybrid buses (i.e., the diesel engine generating power for traction motors and not being directly coupled to the driving axle) and parallel diesel hybrid buses (i.e., the driving axle powered 
either by a traction motor or by the diesel engine through the mechanical gear).

Using the adopted theoretical background, the problem under the study scope has been approached as follows.

The service markets (or more precisely, market segments related to the public transit market) relevant to the electric buses under the study scope have been defined first.

The electric bus powertrains have been then described in technological and managerial terms, to show the technology development as well as limitations in relation to the public transport market requirements.

The electric buses as defined above have been compared among each other and with purely combustion engine vehicles represented by diesel and CNG (compressed natural gas) powertrains, in terms of:

- energy consumption;

- fuel/traction power cost;

- GHG (greenhouse gas) emissions and noise;

- life cycle cost and its likely development;

- operational reliability.

This comparison has been completed by operational parameters such as range or reliability, as found from particular field data ${ }^{2}$.

The relation between urban transport e-mobility and the "smart grid" concept, very much relevant to electric buses but reaching beyond the transport sector, has been explained, based on most up-to-date information from technological media as listed ${ }^{3}$.

Outcomes have been derived from the research, focusing on long term perspectives and recommendations for industries, transport operators and funding public bodies.

\subsection{The Information Sources}

The basis for the study has been a comprehensive

${ }^{2}$ Ibid. 1, p. 46.

${ }^{3}$ Ibid. 1 , p. 46. report prepared on the EU level [1] (hereafter "EU study 2012" and an annual report by the US Department of Energy-The NREL (National Renewable Energy Laboratory)) [2]. These sources have been completed by information from transport operators, manufacturers and dedicated project sources ${ }^{4}$ listed together. This information is presented as 12 case studies (see several shortened examples in Appendix) and product factsheets, focused especially on the bus operational reliability, the powertrain failure percentage, the fuel or traction power consumption and other parameters that are important for a transport operator.

The numbers and figures from these sources are mutually comparable in terms of their particular values just in a very limited way, as different sources use different calculation methodologies and just a few of them cover the full range of parameters under the study scope. Keeping the strategic managerial view is therefore recommendable, rather than trying to get exact outputs from inexact inputs. When doing so, it is notable that most sources show the same or very similar relations among the powertrains under the study scope and the development trends.

\section{Study Results}

\subsection{The Electric Bus Transport Markets}

As defined above, the common urban bus transport on regular routes as a segment in a broadly defined passenger transport market is the key market under the study focus. Serving this market is characterized by:

- Serving routes with different traffic flows and with the lengths ranging from single kilometers to tens of them, with the overall daily mileage of about $200 \mathrm{~km}$ to $250 \mathrm{~km}$, depending on local conditions;

- Operating in a dense street network with short distances between stops that implies frequent acceleration and stopping;

- Adapting to daily and weekly peak and off-peak

${ }^{4}$ Ibid. 1, p. 46. 
demand periods;

- The service availability, reliability and punctuality against the timetable being the essential service quality parameters, as perceived both by passengers and the public service contractors;

- Passenger ambience as another important focus, to keep competitiveness with private motoring or other relevant transport modes.

A $12 \mathrm{~m}$ low floor or low entry urban bus is the most common vehicle for this market. Where the traffic flow density is comparably lower or higher, an 8-9 m midibus or an $18 \mathrm{~m}$ (or even $24 \mathrm{~m}$ ) large bus are used respectively.

Short (often loop) lines in historic urban centers, often serving visitors, or dedicated shuttle services are another market types, not wholly comparable with the standard urban line operation as defined above. As opposed to that, they have much shorter routes (usually just single kilometers), less passenger demand, less stops (especially in case of shuttle services) and a daily mileage of about 50-100 km. Historically, electric minibuses have been widely used to serve such markets since late 1990s, e.g., in Italy. Although they are not under the key study scope, some dedicated case studies from these markets have been used to complete the operational experience.

The vehicle industry market as defined in Section 2 can be seen as a supplier market in relation to this service market.

\subsection{The Energy Storage Sources}

The traction batteries mostly use lithium-ion technologies now. Earlier stage technologies, such as lead-acid batteries or high temperature ZEBRA battery (molten salt batteries) types have been used, especially for electric minibuses. The traction battery concepts are undergoing fast development to increase the power density. However, the effective range for a standard urban bus is still about $130-150 \mathrm{~km}$, given the standard bus design limitations. All recent attempts to increase the range beyond this level have been at cost of the bus seating capacity or increased dead weight which results in increased unit power consumption. Statistical data from an e-bus sample as shown in Fig. 1 demonstrate this assertion. In simple words, $1 \mathrm{~kg}$ of batteries is equally heavy as one kilogram of a human body and a bus is equipped for carrying passengers, that is the point.

Travel ambience or even operational safety may also be an issue when filling the passenger compartment with batteries (a bus of this kind has apparently been taken for "dangerous even if standing on the street" by some local authority). The technological development is therefore focused on slow charging overnight combined with fast charging on the route, which is defined above as "opportunity e-bus".

The varieties of slow (more than $1 \mathrm{~h}$ ) or fast (less than $1 \mathrm{~h}$ ) e-bus charging concepts range from plug-in charging, through different types of roof charging arms or pantographs, to inductive contactless charging. The charging time is adequate to the necessary re-charged energy and to the charging performance $(50 \mathrm{~kW}$ or 100 $\mathrm{kW}$ or even more by fast charging). A plug-in charging with different standard socket and protection equipment types are still most common. A pantograph charging from a bi-pole catenary has been adopted, e.g., in Vienna. The ABB's "flash charging" concept using a laser navigated robotic arm on the vehicle roof and capacitor supported very fast charging stations on the route (15 s charging time by $400 \mathrm{~kW}$ charging performance) has been introduced in Geneva in May 2013. Contactless inductive charging has been adopted, e.g., on a Turin minibus fleet in early 2000s while some other trial operation has just been running, e.g., in Braunschweig (Germany) with standard buses or in Milton Keynes (UK) with midibuses. Battery swapping concept has been adopted especially by lead-acid batteries on minibus operation in the electric bus early development stage, e.g., in France.

None of these concepts is "far the best" or "ideal". Particular transport market requirements and operational conditions (such as the geographical and climatic 


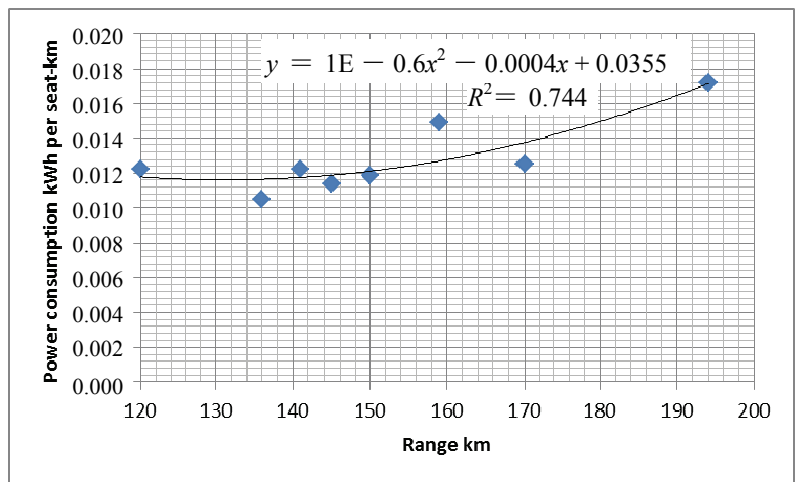

Fig. 1 The dependence between range and power consumption (the seat-km cover also the standing passenger capacity).

conditions, the distance between stops, the headways between services or the road surface quality) have to be weighed against the technology performance parameters and cost, to deliver the best possible value for money both to the passengers and to the public service contractor.

The fuel cell mobile applications use mostly the PEM (proton exchange membrane) concept (Fig. 2).

The term "fuel cell powertrain" may not be always identical with "hydrogen powertrain" as there are also hydrogen powered combustion engine buses (used, e.g., in Berlin) or, vice versa, methanol fuel cells currently experiencing their renaissance for vehicle applications.

Supercapacitors (also "ultracapacitors") are sometimes used as additional (or, exceptionally, the only) power storage, managing for the very high and short performance requirements on the bus moving off.

Hybrid combinations for both diesel hybrid buses and fuel cell buses have been employed as a considerably energy saving concept, despite their high demand for system integration (Fig. 3).

\subsection{The Traction Energy Consumption and Cost}

As Fig. 4 suggests, all the sources under research show the same powertrain ranking by traction energy consumption, disregarding the differences in their actual values: a $\mathrm{CNG}$ engine as the most energy consuming powertrain, followed by sole diesel, diesel hybrid (an average of the serial and parallel concepts), fuel cell and purely electric powertrains by e-buses and trolley-buses. This just reflects and confirms the general powertrain physics in practice. The high values by the CNG powertrain are generally caused by energy inefficiencies in the combustion process. The differences between the reference study [1] and the field data are caused simply by different conditions by the operators as well as different methodologies for data acquisition and processing. However, disregarding the data source, the results give a clear message about

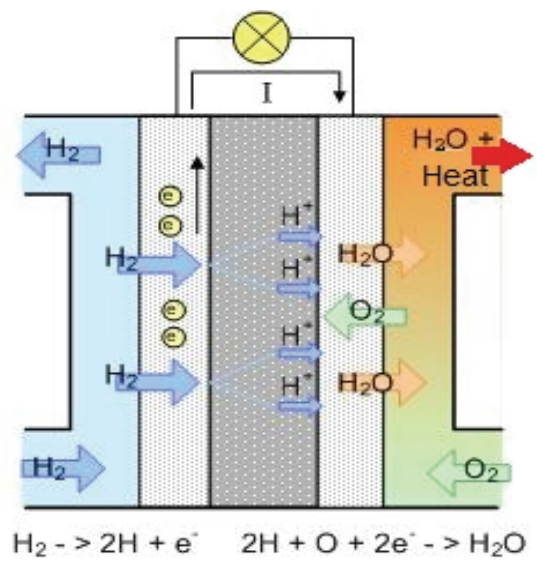

Fig. 2 The PEM fuel cell scheme.

Source: ÚJV Řež, a.s..

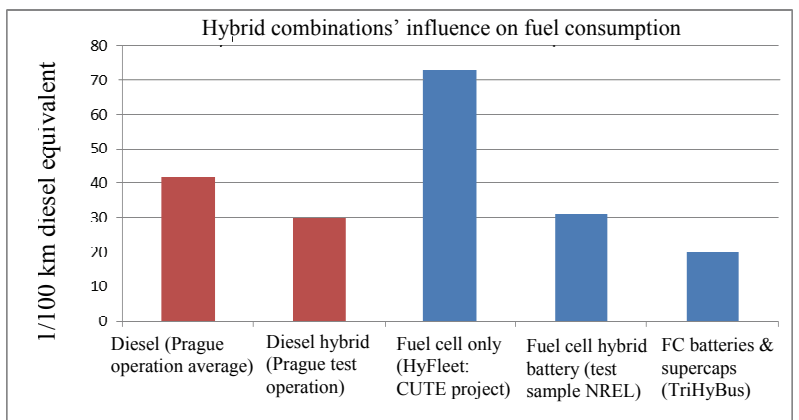

Fig. 3 The hybrid concept influence on the fuel consumption $[2]^{5}$.

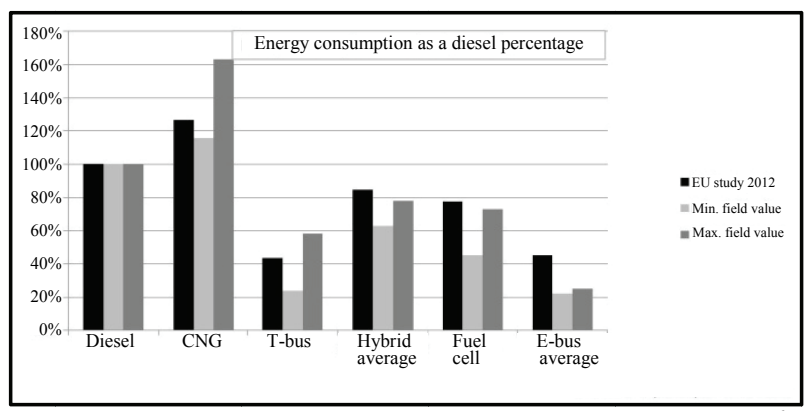

Fig. 4 The powertrain energy consumption comparison $[1]^{6}$.

${ }^{5}$ Ibid. 1, p. 46.

${ }^{6}$ Ibid. 1, p. 46. 


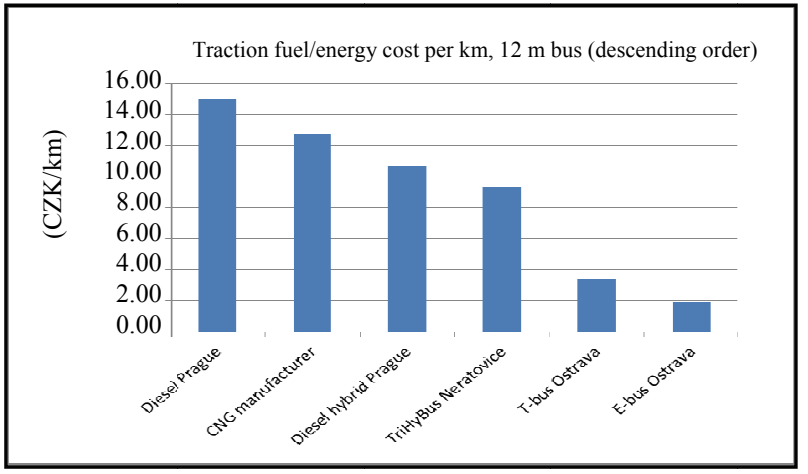

Fig. 5 The powertrain energy cost comparison.

the powertrains' energy efficiencies in their mutual comparison.

When projected into the fuel or traction energy costs in the Czech market from the field research sources (see also in Appendix), the CNG powertrain energy inefficiency is partially outweighed by the fuel low cost (as influenced by the national tax policy, rather than by its production cost), but it still remains higher than all electric powertrains including diesel hybrids, as Fig. 5 shows. The difference between e-bus and trolley-bus in this case results from the particular e-bus light design (see in Appendix) compared to a standard design trolley-bus.

\subsection{The Environmental Impacts}

As Fig. 6 shows, the powertrains under research vary considerably in the well-to-tank, tank-to-wheel and the well-to-wheel GHG emissions. For the study purpose, an average between the most cost effective and the most environment-friendly alternative in Ref. [1] has been used as an all-European basis for the well-to-tank GHG emissions. This may vary by particular countries, depending on their real power generation structure and on the particular power generation facilities' conditions that may differ from each other.

It is notable that both well-to-wheel and tank-to-wheel GHG emissions by diesel hybrids of both concepts are lower than those by the CNG powertrains. It is also important to see that even when considering the well-to-tank GHG emissions by electric powertrains, they are still more environment

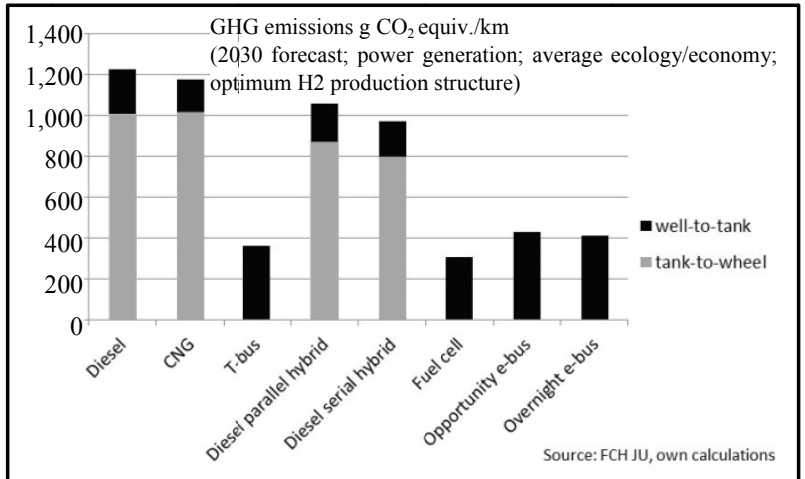

Fig. 6 The powertrain GHG emission comparison [1].

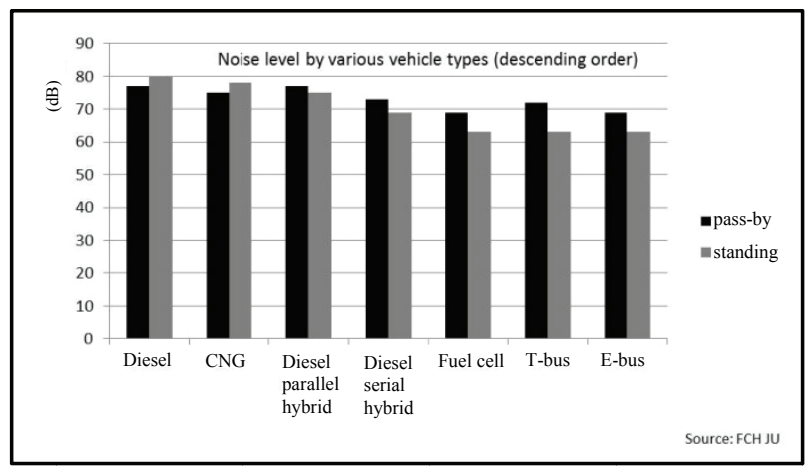

Fig. 7 The powertrain noise level comparison [1].

friendly, both locally and globally, than those powertrains using combustion engine only. This is especially relevant for the Czech Republic whose electric energy mix (considering carbon and non-carbon source structure) is very similar to the EU average. Newly available information sources after the study publishing, such as Ref. [3], confirm these relations in general as well.

Fig. 7 shows the noise level that, again, confirms the low noise by using electric powertrains as compared with sole combustion engines. As obvious, standing electric vehicles make almost no noise except for auxiliary devices and run very quietly yet not in absolute silence when in movement, as opposed to combustion engine vehicles.

The environmental influences by particular transport modes and powertrains could be (and are) subject to detailed research outside the study scope. It can be summarized, nevertheless, that electric powertrains appear to be more energy efficient and environment friendly in European conditions, especially in urban 
transport regime as described above. There may be differences in the particular values, depending on both the transport operation parameters and the national energy mix.

\subsection{The Cost}

The total cost of ownership per kilometer, i.e., the sum of financing, purchase, infrastructure and running cost including the emission penalty according to the EC Directive 2009/33, has been calculated for particular powertrain type in Ref. [1]. In the study, these numbers have been compared with the field findings from various sources ${ }^{7}$. As noted above, these sources are not wholly comparable: None of them covers the total cost of ownership as defined here. Also, various methods and approaches including expert estimations have been applied by calculating them. Interestingly, the relations between Ref. [1] and the maximum and minimum results found ${ }^{8}$ are very similar, as Fig. 8 shows.

This just confirms that own calculations and expectations by manufacturers and transport operators addressed in the study preparation process are similar to the expert pool considerations in Ref. [1].

As obvious, the market development stage and hence, the economies of scale play an important role by the calculated cost per kilometer (comparing prototype or small series production by electric buses to diesel bus mass production), together with the vehicle lower availability by the e-bus and fc-bus trial fleets influencing the annual mileage. Paradoxically, as the case studies show, the availability problems just seldom relate to the powertrain issues, but mostly to plain mechanical failures (see in Appendix). On the other hand, a considerable minimum can be seen in the e-bus field data if the vehicles are produced and operated cost-effectively (see the Ostrava example in Appendix). A costly infrastructure burdens trolley-buses, outweighing their mature market stage.

${ }^{7}$ Ibid. 1, p. 46.

${ }^{8}$ Ibid. 1, p. 46.
While e-buses and fuel cell buses show the higher per-kilometer cost, they also show the highest potential for cost reduction, as foreseen by Ref. [1] and shown in Fig. 9.

This is especially due to their anticipated growing economies of scale. The foreseen cost growth by trolley-buses is caused mainly by the anticipated growth in the labour price connected to the infrastructure. However, development in technologies, such as trolley-buses with range extenders (see also below), may influence this trend notably.

\subsection{The Operational Reliability}

In the EU and US reports available to us, the issue of operational reliability has been addressed just in Ref. [2] when analyzing miles between road calls by fuel cell buses, CNG buses and diesel hybrids. There was, however, nothing about e-buses there. It was therefore decided to compare the case study results for e-buses, fc-buses and diesel hybrids in terms of vehicle operational availability as the measure in general terms

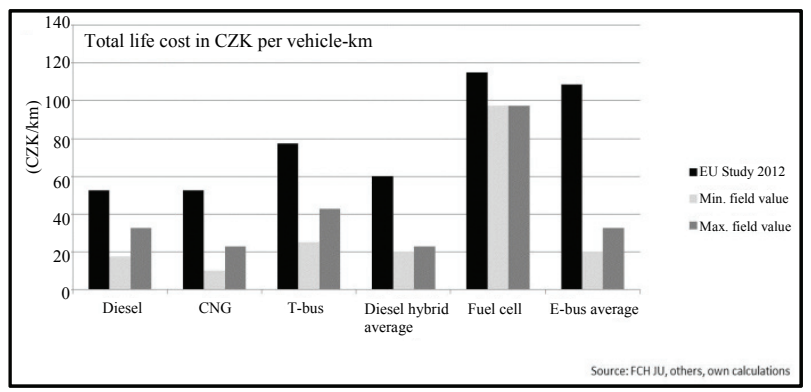

Fig. 8 The vehicle total cost per kilometer.

Source: Refs. [1, 2] $]^{9}$ and own calculations.

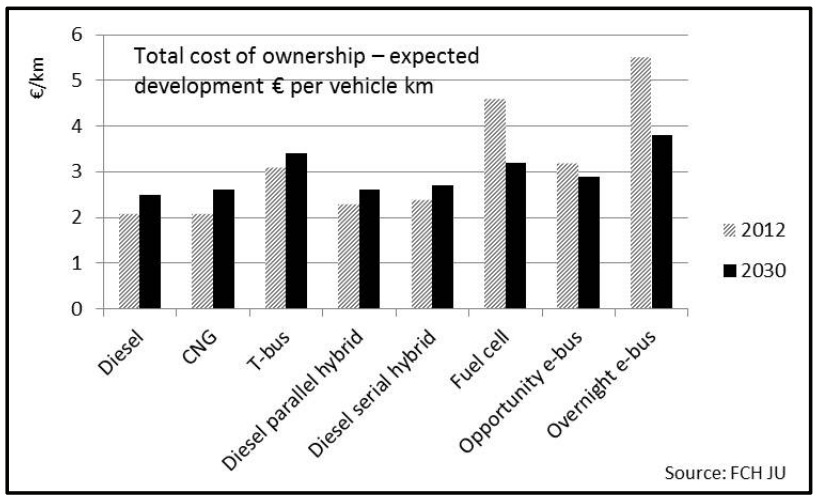

Fig. 9 The total cost of ownership expected development (source: Ref. [1]).

${ }^{9}$ Ibid. 1, p. 46. 
(i.e., not precisely according to the technical definition of "reliability").

As Fig. 10 shows, all these vehicle types have demonstrated a good availability at the upper levels of the value ranges, fully comparable to conventional vehicles. The least range, i.e., the least difference between the best and the worst case, can be seen by e-buses. This is caused especially by the e-bus powertrain's relatively simple design. The best availability, but also the most significant difference between the best and the worst case, can be seen by diesel hybrids. This confirms the fact that these vehicles can be very reliable, but it depends very much on a particular design from a particular supplier. The fc-buses are in the middle, influenced especially by two factors: the fleets' generally very small sizes and mechanical problems as the most common reason for unavailability — see above. Surprisingly or not, the fuel cell itself has been the least vulnerable part of an fc-bus powertrain.

This all shows that the electric bus reliability is influenced especially by the particular vehicle design and assembly rather than by the powertrain in general. Also, marginal mechanical failures (such as a broken outside mirror) may cause vehicle unavailability negligible by large fleets but notable by a single vehicle.

\subsection{The Problems and the Solutions}

Nothing in the world is ideal. However, each problem is an opportunity for a new solution. This applies also for electric buses.

The e-bus limitations given by their low daily range due to the achievable power density by current traction batteries can be resolved by charging on the route. This results in the "opportunity e-bus" concept as defined in Section 2.1. The daily range limitation can also be removed by using e-buses on peak hour services with intermediate recharging, as the Ostrava case in Appendix shows.

Fuel cell buses are the other very promising electric bus concept as the only catenary free electric alternative having a single filling range comparable with combustion engine powertrain. Bringing it into a series production, however, still needs much research and development as well as the hydrogen infrastructure high initial investment.

Both e-buses and fc-buses as technologies in the early development stage require much external resources-human, technological and financial-for industrial research and development, to be covered by public bodies and by the industries. Regrettably, public-private research and development projects of this kind comprising research universities, manufacturers and transport operators, as common in Western Europe and the USA, are still rare in the Czech Republic. The current EU and other international programs and initiatives (such as the Horizon 2020 or CIVITAS) motivating cities and other related subjects to participate in such projects may change this situation.

It should be stressed that transport operators' participation in such projects is inevitable as no laboratory can create realistic operational conditions and generate the respective feedback data. This, however, needs financial stimulation to the operators to take the risk of a trial vehicle unavailability or unreliability.

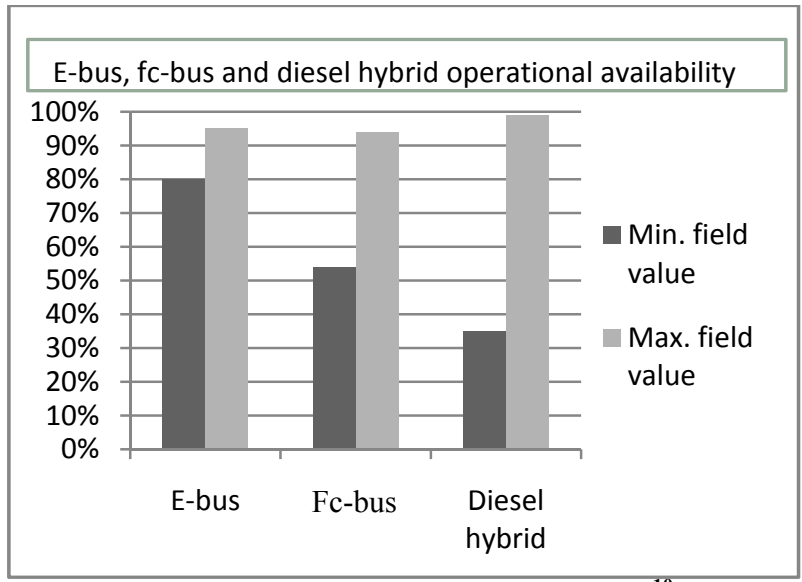

Fig. 10 The electric bus operational availability ${ }^{10}$.

Source: field research.

${ }^{10}$ Ibid. 1, p. 46. 
The trolley-bus dependence on expensive infrastructure can be lowered or partially removed by a catenary free operation using batteries, capacitors or (less environment friendly) a combustion engine powered range extender. The "flash charging" technology as mentioned in Section 3.2 offers an opportunity of a combination between a trolley-bus and an opportunity e-bus.

Diesel hybrid powertrains suffer from the myth of being unreliable and over-expensive, as integrating two powertrains in a single vehicle. As the examples in Appendix, the reliability depends very much on particular design and the manufacturer's experience and in particular cases, it may be much better than by conventional vehicles. This should be subjected to market forces and the customer negotiation power, to get the best value for money from the producer. Also, a clever approach to the fleet enlargement by the public bodies as demonstrated on the London case in Appendix may strengthen the overall use of this technology.

Last, but not least, the human factor and the overall corporate culture are very important for a successful electric bus implementation. Handy electrical engineers by tram or trolley-bus operators coming up with "We have a substation nearby. We'll just pull a cable from there, no problem." are the best example of that.

\subsection{Electric Buses and the "Smart Grid" Concept}

Electric buses are not just an environment friendly alternative for urban transport. They may also be an important part of a "smart grid" concept as Fig. 11 shows.

The "smart grid" concept means an "intelligent" power generation, transmission, distribution and consumption scheme. It includes the grid, the power generation sources and the consumers integrated and interconnected by information and communication technology in a way continually balancing the power demand and supply and optimizing the power consumption. In Fig. 11, the consumers are represented just by urban transport, but obviously, the whole smart grid also involves all other kinds of consumers-households, industries and other services.

On the vehicle end, there is an opportunity for "intelligent" e-bus charging, reflecting the immediate supply-demand situation in the grid. Although it can be hardly expected in practice now that traction batteries on vehicles, very sensitive to uncontrolled charging and discharging, can serve as energy storages, batteries at the end of their "mobile" life (i.e., having the $30 \%$ or more degradation, but still usable) can do this service in a stationary regime well.

Recuperation into the power distribution grid (i.e., not just into the catenary network) by trolley-buses and rail vehicles is also a part of the smart grid concept.

Hydrogen infrastructure for fuel cells is another part of the network on the vehicle end. Moreover, methanol fuel cells experience their renaissance for mobile applications now, though not yet used for bus powertrains.

On the power supply end, renewable sources can feed the grid by environment-friendly produced power. They will mostly work together with conventional sources including carbon-free and hence, environment friendly-nuclear power, experiencing slow but notable progress towards sustainability (IV gen reactors or small reactors). The outstanding power from the renewables can be stored in form of hydrogen or methane in the gas network and used again as electricity either through gas power plants or through fuel cell technologies. This shows the "rivals"-electricity and gas, interconnected into a single "clever" energy network.

The timetable driven circulation on the defined routes and hence, the quasi-deterministic system behavior by the public transport offers many opportunities for synergies within the smart grid concept, more than by-rather stochastic-private electric car operation. 


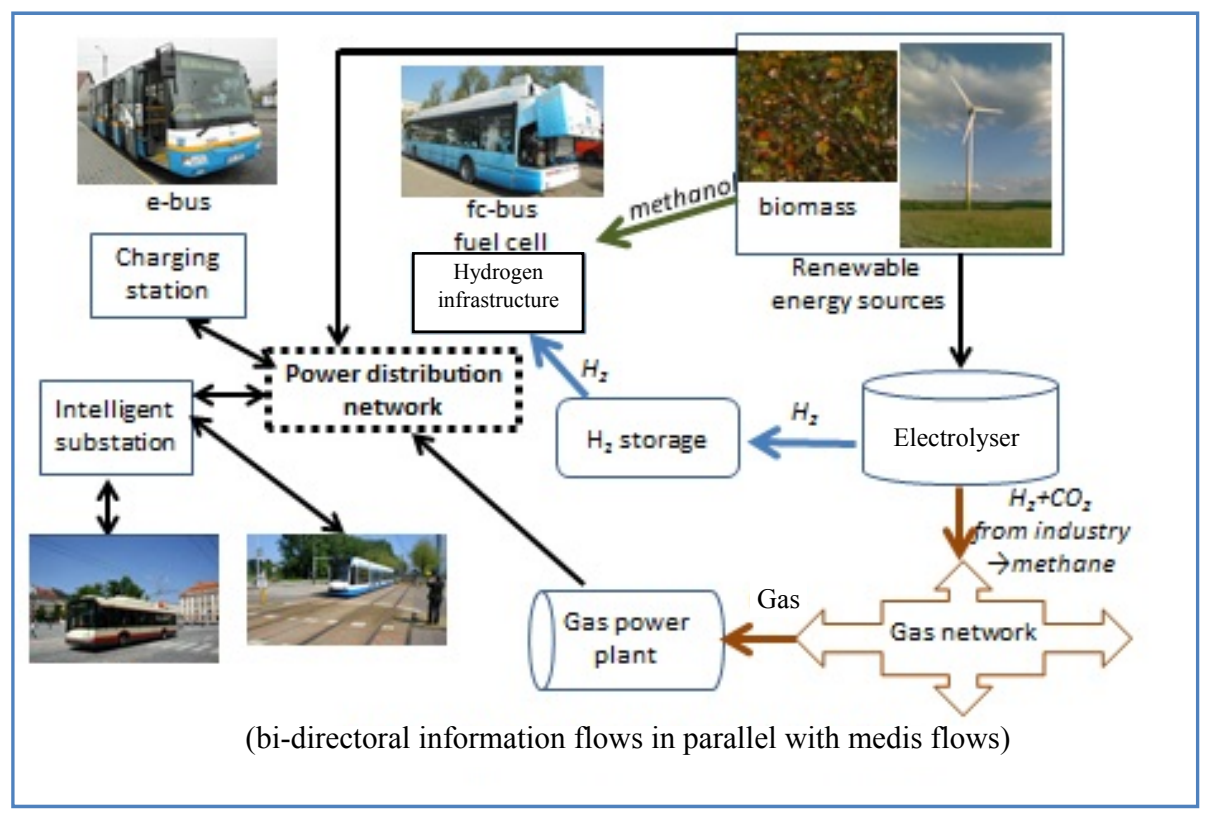

Fig. 11 Electric buses and the "smart grid" concept.

The smart grid concept or the smart city concept (when combining sustainable urban mobility, sustainable built environment and the integrated infrastructure) has already been experiencing trial applications in various forms and various stages worldwide. Moreover, most of the described technologies are just available, either as a standard commercial product (such as intelligent substations) or as equipment undergoing extensive trial operation (such as several "power-to-gas" projects).

It seems, however, that common technological issues are not that crucial for implementing these concepts in practice as business or purely human issues.

For example, while an electric transit operator is motivated to save electricity and the technology enables that, the power producer and distributor, on the contrary, wants to sell as much electricity as possible. Thus, e.g., installing an intelligent substation may threaten meeting the contractual obligations on the transit operator's end. Using the saved electricity for charging other electric vehicles (such as e-buses) is a good solution of that problem, applied in practice, e.g., in Vienna (see in Appendix).

Also, even environment aware consumers may be very conservative to change their habits in everyday practice, unless having a very good reason for doing so.

Not surprisingly, exploring suitable business models is usually an important part of most related projects or studies.

Data (or cyberspace) security as a separate (and serious) problem package far beyond the study scope is another key issue when implementing the smart grid or smart city concept in a large scale practice. Simply speaking, no one is really interested in allowing a creative hacker (not necessarily a terrorist) to cause a local black-out or another disaster when attacking the information network being a part of the smart grid.

This can just show in a nutshell why these concepts are not just a matter of suitable products and sufficient budgets, but they need to be developed in their full complexity.

Information about the smart grid or smart city concepts and the related technologies is continually followed by technological media as listed ${ }^{11}$.

\section{Conclusions}

The study has shown that although different sources

${ }^{11}$ Ibid. 1, p. 46. 
show different values, the principal conclusions for the current state, development trends and future opportunities of electric powertrains for urban transport including urban buses are mutually in accordance.

The electric powertrain technology develops very fast and offers a big variety of opportunities for particular transport market conditions and requirements. It therefore needs to be continually watched and assessed, to tailor the most suitable technology and operational solutions for each particular transport market conditions.

Opportunity e-buses (recharged on the route) and fuel cell buses are the most promising bus technologies for the future urban transport e-mobility in terms of operational parameters, cost, environmental effects as well as long term national energy strategies. They, however, need much public as well as private investment to the research and development.

Diesel hybrid buses are a developed product competing to CNG buses in terms of costs and showing better environmental parameters. They, as a product in a developed market, should be sensibly supported within urban public transport subsidizing processes, leaving enough space to market forces to deliver the best possible value for money.

Trolley-buses can use new energy storage and charging technologies, to outweigh the disadvantage in dependence on the catenary as well as high infrastructure cost. The note about urban public transport subsidizing applies here as well, considering also the necessary infrastructure renewal.
Transport operators' close participation in the related research and development is necessary to obtain real and reliable field data that cannot be supplemented by laboratory tests. Such participation, however, needs to be stimulated financially, to compensate for inevitable operational risks caused to the operator by unproven equipment. While such public-private projects can be found in Western Europe and the USA, they are still just a rare phenomenon in the Czech Republic which, however, may change very soon.

The electric urban transport (including electric buses) involvement in the "smart grid" concept and the resulting opportunities within as well as beyond the transport sector should be carefully followed on the government level and the concept development should be supported by public funding or co-funding.

\section{References}

[1] Fuel Cells and Hydrogen Joint Undertaking. 2012. Urban buses: Alternative powertrains for Europe. Fact-based analysis of the role of diesel hybrid, hydrogen fuel cell, trolley and battery electric powertrains.

[2] Eudy, L., Chandler, K., and Gikakis, C. 2012. Fuel Cell Buses in U.S. Transit Fleets: Current Status 2012. Technical report NREL/TP-5600-56406.

[3] Civitas WIKI Consortium. 2013. Civitas Policy Note: Smart Choices for Cities-Clean Buses for Your City. Civitas WIKI project report.

[4] Johnson, G., Scholes, K., and Whittington, R. 2008. Exploring Corporate Strategy. Harlow: Pearson Education Limited.

[5] Chapman, D., and Cowdell, T. 1993. Understanding and Managing Public Sector Markets. Sheffield: Sheffield Business School.

\section{Appendix: Examples of Electric Bus Operation}

\section{(1) "100 Bus Electrique" Project (France)}

Key features:

E-minibus example - vehicle type, operation and parameters not wholly comparable with standard buses.

Trial project in France:

18 cities;

70 small and medium e-buses_-various types with 22-55 seats;

Analysed data from IQ 2005; 
Various traction batteries ( $\mathrm{Pb}, \mathrm{Ni}-\mathrm{Cd}$ and ZEBRA) with capacities 42-160 kWh;

$\mathrm{Pb}$ batteries: exchange during the day (5-6 $\mathrm{min})$;

$\mathrm{Ni}-\mathrm{Cd}$ and ZEBRA batteries: overnight charging (Ni-Cd also charging on the route) ;

Battery management by suppliers;

Operating especially on short loop routes in historic city centres or on shuttle services;

Daily mileage: Ca 100 km;

Availability: $95 \%$;

Power consumption: $0.6-1.2 \mathrm{kWh} / \mathrm{km}$;

Successful in historic centres; need for higher capacity and daily mileage for standard line operation.

(2) E-buses in Vienna (Austria)

Key features:

A fleet of 12 Siemens/Rampini e-buses-7.7 m Alè electric type.

Overall capacity: 46 passengers.

Siemens ELFA powertrain using $96 \mathrm{kWh}$ Lithium-Ferrite batteries.

Recharged at termini during the regular 10-15 min operational pause through a bi-pole pantograph from a 600V DC tram catenary branch line completed by the second conductor connected to the running rail (similar to trolley-bus catenary).

Overnight balance charging using the same infrastructure type.

Range per one charging: $120 \mathrm{~km}$.

In regular operation since 2013 - circular lines in the inner city; the fleet daily circulation is about $1000 \mathrm{~km}$.

Full day operation- $13.5 \mathrm{~h}$.

Power consumption: $1 \mathrm{kWh} / \mathrm{km}$.

Cheap infrastructure - just a branch line from thetram catenary.

Double investment cost, but $28 \%$ savings in operational cost compared to diesel buses.

(3) E-buses in Ostrava (Czech Republic)

Key features:

A fleet of four SOR EBN 10.5 e-buses-10.5 m light urban bus design.

Overall capacity: 85 passengers (comparable with $12 \mathrm{~m}$ buses).

Li-Ion batteries $170 \mathrm{kWh}$; range per one charging $140 \mathrm{~km}$ (with passengers).

In regular operation since 2010; analysed data from III. and IV. Q/2012.

Regular line operation in peak hour shifts:

Morning circulation: $85 \mathrm{~km}$ - traction batteries discharged to $60 \%-70 \%$; fast charging in depot during1 h.

Afternoon circulation $100 \mathrm{~km}$; overnight slow charging in $7 \mathrm{~h}$.

Availability: $83 \%$.

Most often mechanical failures; powertrain failures: $12 \%$ of repairs.

Power consumption: $0.89 \mathrm{kWh} / \mathrm{km} ; 32 \%$ recuperation.

Vehicle price: CZK $8.5 \mathrm{mil}(€ 340 \mathrm{k})+\mathrm{CZK} 2 \mathrm{mil}$ new batteries.

Total life cost per kilometer: CZK32.8, i.e. $€ 1.31$ (=98\% of a dieselbus and $78 \%$ of a trolley-bus in comparable local conditions). 
(4) Fuel Cell Buses by the SunLine Transit Agency (USA, California)

Key features:

Two types of $12 \mathrm{~m}$ fuel cell-buses:

(a) New Flyer: $150 \mathrm{~kW}$ FC; Li-ion batteries $47 \mathrm{kWh}$;

(b) ElDorado National: $159 \mathrm{~kW}$ FC, Li-Ion batteries $11 \mathrm{kWh}$; (data: a/b if not stated otherwise).

fc bus line operation since 2006, analysed data from 2010-2012.

Range per tank filling: 460/560 km.

Availability: $62 \% / 71 \%$.

Problems with traction batteries most frequent; fuel cells showed least failures (20\%).

Fuel consumption: 9.8/9 kg/100 km (diesel equivalent of 33/30 km 1/100 km).

Vehicle price: \$1.2 mil (New Flyer).

Total cost per kilometer: $\$ 4.82$ (New Flyer).

(5) TriHyBus Project (Czech Republic)

Key features:

fc bus prototype based on $12 \mathrm{~m}$ Irisbus Citelis design.

Overall capacity: 96 passengers.

EU demonstration project led by ÚJV Řež; electric powertrain and system integration by Škoda Electric.

The only Czech and the first Central and Eastern European fc-bus project and hydrogen filling station.

Triple hybrid design:

$50 \mathrm{~kW} \mathrm{fc}$;

Li-ion batteries $26 \mathrm{kWh}$.

Ultracapacitors: $1 \mathrm{kWh}: 200 \mathrm{~kW}$ by acceleration and $300 \mathrm{~kW}$ by braking.

Demonstration rides and regular urban line operation in Neratiovice.

Project start 2008; analysed data from 2012-2013.

Range per tank filling: $275 \mathrm{~km}$.

Vehicle availability: 90\%; just one failure (mechanical—braking pedal).

Hydrogen infrastructure is a problem: long waiting for failure removal.

Fuel consumption: $7.75 \mathrm{~kg} / 100 \mathrm{~km}$ (diesel equivalent of 201/100 km).

Total project cost: $€ 3.3$ mil, of this ca $1 / 3$ hydrogen infrastructure, $1 / 3$ bus development and $1 / 3$ bus production.

Triple hybrid design: maximum efficiency, but still uncertain future - dedicated further project owner needed to carry out field tests and to implement the results.

(6) London Diesel Hybrid Buses (the UK)

Key features:

207 diesel hybrid buses with various designs from various producers and mainly $\mathrm{Li}$-ion batteries.

(a) Trial fleet: $12 \mathrm{~m}$ buses — single-deckers and double-deckers;

(b) Green Bus Fund fleet: most reliable types (Alexander Dennis Limited and Volvo) — double-deckers only seven operators on 16 routes. Analysed data from 9/12/2012.

Availability:

Trial fleet: $87 \%(36 \%-99 \%)$. 
Green Bus Fund fleet: 99\%.

Hybrid powertrain failure percentage: $4 \%-78 \%$.

Fuel consumption: 21.4-55 1/100 km (differences between SD/DD (single decker or double deckers)) buses).

Average fuel savings enabled by hybrid powertrain: $30 \%$.

Differences by manufacturers and designs rather than by concepts (serial or parallel hybrid).

Successful hybrid bus operation: 20\% hybrids of total 8,500 London buses currently planned for 2016 .

(7) Diesel Hybrid Trial Operation in the Czech Republic

Key features:

Volvo 7700 hybrid urban bus.

Overall capacity: 95 passengers.

A parallel hybrid; Li-ion battery $1.2 \mathrm{kWh}$.

Trial operation.

(a) Prague - a high loaded urban route;

(b) Chomutov - suburban operation in a hilly landscape; (data a/b if not stated otherwise).

Analysed data from June/September 2012.

Overall availability: $88 \%$.

Minor mechanical failures and accidents.

Hybrid powertrain availability: $100 \%$.

Fuel consumption: 30.4/30.6 1/100km.

Average fuel saving resulting from the hybrid powertrain: $28 / 20 \%$ - a more obvious saving in urban operation.

An above-average reliability of a well proven design ( 3 years in series production) demonstrated. 